OPEN ACCESS

Edited by:

Natasa Petronijevic, University of Belgrade, Serbia

Reviewed by: Jumpei Sasabe, Keio University, Japan Kenji Hashimoto,

Chiba University, Japan

${ }^{*}$ Correspondence:

Joshua T. Kantrowitz jk3380@cumc.columbia.edu

Specialty section:

This article was submitted to

Psychopharmacology,

a section of the journal

Frontiers in Psychiatry

Received: 16 June 2021

Accepted: 13 July 2021

Published: 10 August 2021

Citation:

Meftah A, Hasegawa H and Kantrowitz JT (2021) D-Serine: A Cross Species Review of Safety.

Front. Psychiatry 12:726365. doi: 10.3389/fpsyt.2021.726365

\section{D-Serine: A Cross Species Review of Safety}

\author{
Amir Meftah $^{1,2}$, Hiroshi Hasegawa ${ }^{3}$ and Joshua T. Kantrowitz ${ }^{1,2,4 *}$ \\ ${ }^{1}$ College of Physicians and Surgeons, Columbia University, New York City, NY, United States, ${ }^{2}$ New York State Psychiatric \\ Institute, New York City, NY, United States, ${ }^{3}$ Department of Pathophysiology, Tokyo University of Pharmacy and Life \\ Sciences, Tokyo, Japan, ${ }^{4}$ Nathan Kline Institute, Orangeburg, NY, United States
}

Background: D-Serine, a direct, full agonist at the D-serine/glycine modulatory site of the N-methyl-D-aspartate-type glutamate receptors (NMDAR), has been assessed as a treatment for multiple psychiatric and neurological conditions. Based on studies in rats, concerns of nephrotoxicity have limited D-serine research in humans, particularly using high doses. A review of D-serine's safety is timely and pertinent, as D-serine remains under active study for schizophrenia, both directly (R61 MH116093) and indirectly through D-amino acid oxidase (DAAO) inhibitors. The principal focus is on nephrotoxicity, but safety in other physiologic and pathophysiologic systems are also reviewed.

Methods: Using the search terms "D-serine," "D-serine and schizophrenia," "D-serine and safety," "D-serine and nephrotoxicity" in PubMed, we conducted a systematic review on D-serine safety. D-serine physiology, dose-response and efficacy in clinical studies and DAAO inhibitor safety is also discussed.

Results: When D-serine doses $>500 \mathrm{mg} / \mathrm{kg}$ are used in rats, nephrotoxicity, manifesting as an acute tubular necrosis syndrome, seen within hours of administration is highly common, if not universal. In other species, however, D-serine induced nephrotoxicity has not been reported, even in other rodent species such as mice and rabbits. Even in rats, D-serine related toxicity is dose dependent and reversible; and does not appear to be present in rats at doses producing an acute Cmax of $<2,000 \mathrm{nmol} / \mathrm{mL}$. For comparison, the Cmax of D-serine $120 \mathrm{mg} / \mathrm{kg}$, the highest dose tested in humans, is $\sim 500 \mathrm{nmol} / \mathrm{mL}$ in acute dosing. Across all published human studies, only one subject has been reported to have abnormal renal values related to $\mathrm{D}$-serine treatment. This abnormality did not clearly map on to the acute tubular necrosis syndrome seen in rats, and fully resolved within a few days of stopping treatment. DAAO inhibitors may be nephroprotective. D-Serine may have a physiologic role in metabolic, extra-pyramidal, cardiac and other systems, but no other clinically significant safety concerns are revealed in the literature.

Conclusions: Even before considering human to rat differences in renal physiology, using current FDA guided monitoring paradigms, D-serine appears safe at currently studied maximal doses, with potential safety in combination with DAAO inhibitors.

Keywords: NMDA-N-methyl-D-aspartate, D-serine, schizophrenia, safety, kidney 


\section{INTRODUCTION}

Glutamate-targeted drugs remain a high priority for the treatment of schizophrenia $(1,2)$. While no compounds have successfully navigated the difficult process from Phase I to regulatory approval, recent meta-analyses support significant, moderate to large effect size improvements for both schizophrenia symptoms in general, along with specific improvements in negative symptoms, for pooled N-methylD-aspartate-type glutamate receptors (NMDAR) modulators adjunctive to antipsychotics compared to placebo (3). In addition to overall improvements in residual psychotic and negative symptoms, glutamatergic based medications have also targeted cognitive deficits $(4,5)$.

The vast majority of glutamate-based treatment trials have targeted the glycine modulatory site of the NMDAR with natural compounds such as D-serine, glycine, and sarcosine. Recently, the field has seen some successes and some failures with more traditional pharmaceutical glutamatergic treatment trials (5-8). In particular, dose finding, target engagement biomarker work has helped to guide the field $(1,9)$, allowing an assessment of the ideal doses of the correct compounds to use prior to larger Phase II studies.

The present report focuses on the safety of D-serine, one of the more thoroughly studied NMDAR modulators (3), with a specific focus on potential nephrotoxicity. A review of $\mathrm{D}$ serine's safety is timely and pertinent, as D-serine remains under active study, both directly (10), and indirectly through D-amino acid oxidase (DAAO) inhibitors such as Luvadaxistat (NBI1065844/TAK-831) and NaBen (sodium benzoate). In addition to a primary focus on D-serine and renal safety, specific topics covered include an overview of D-serine's physiology, efficacy and dose-response in treatment studies, physiology/pathophysiology in other systems and potential metabolic, extra-pyramidal, cardiac, and oncological adverse events and interaction with DAAO inhibitors.

\section{METHODS}

Using the search terms "D-serine," "D-serine and schizophrenia," "D-serine and safety," "D-serine and nephrotoxicity" in PubMed, we conducted a systematic review on D-serine safety. The reference lists of articles found were reviewed for additional sources.

\section{OVERVIEW OF D-SERINE PHYSIOLOGY}

Glutamate is the primary excitatory neurotransmitter in the brain, and the NMDAR is the primary glutamate receptor (11, 12). In addition to the primary binding site of glutamate, the NMDAR is modulated by multiple other binding sites. D-Serine is a naturally occurring amino acid that is present in high concentrations in the human brain $(13,14)$. D-Serine is an NMDAR modulator and a full agonist at the D-serine/glycine site of the NMDAR $(15,16)$. Binding by D-serine or glycine at this modulatory site is necessary for activation of the NMDAR (11).
$\mathrm{D}$-Serine is the D-isomer of the more common amino acid $\mathrm{L}$-serine. Along with $\mathrm{D}$-aspartate and $\mathrm{D}$-alanine, $\mathrm{D}$-serine is one of the few D-amino acids present in high concentrations in the mammalian brain (or elsewhere in the human body), suggesting an important physiological role (17). The normal source for $\mathrm{D}$-serine in brain appears to be conversion from L-serine, via serine racemase $(18,19)$. D-serine is converted to back to $\mathrm{L}$ serine only to a limited degree, but in cortical areas with low $\mathrm{DAAO}$, serine racemase appears to degrade $\mathrm{D}$-serine via $\alpha / \beta$ elimination of water (20). In general, D-serine is broken down through the action of DAAO (14). In rodents, DAAO is primarily expressed in the cerebellum (21), with only a limited expression in rodent forebrain (22), and thus appears to play a limited role in $\mathrm{D}$-serine degradation in this area $(23,24)$. DAAO inhibition can modulate hippocampal function in rodents (25). In humans, DAAO is present in both cortical neurons and cerebellar glia (26).

Serine racemase is also present outside the brain (27), but preclinical studies suggest that it is less clearly involved in D-serine regulation in the periphery (28). By contrast, DAAO appears to be physiologically active in the periphery, with the largest expression in the cerebellum, small intestine, liver, and kidney $(17,29,30)$. Thus, DAAO inhibitors appear to exert their putative therapeutic effects via reduced peripheral degradation of $\mathrm{D}$-serine rather than by direct cortical action.

In humans, D-serine exhibits linear kinetics (31), with a TMax $\sim 1-2 \mathrm{~h}$ following administration (Figure 1, Left) and a $\mathrm{t}^{1 / 2}$ of $\sim 3.3 \mathrm{~h}$. The CMax of D-serine is $120.6 \pm 34.6,272.3 \pm 62.0$, and $530.3 \pm 266.8 \mathrm{nmol} / \mathrm{ml}$ for the 30,60 , and $120 \mathrm{mg} / \mathrm{kg}$ doses, respectively (31). After 4 weeks of daily treatment, linear kinetics continued to be observed, although there may be some modest accumulations (Figure 1, Right).

D-Serine can cross the blood brain barrier, supporting the potential utility as a therapeutic agent $(32,33)$. Both D-serine and glycine have shown promise in clinical trials, although Dserine may be more pharmacologically potent than glycine (3438 ) and is the main NMDAR regulator in cortex. Relevant to its potential as a cognitive enhancer (39), D-serine also has a specific role in long-term potentiation (LTP) and depression (LTD) (40$42)$, long-term plasticity $(43,44)$ and synaptogenesis (45). Studies suggest a basal deficit in D-serine in schizophrenia $(31,46)$, further supporting a role for D-serine as a treatment.

\section{USE OF D-SERINE IN TREATMENT STUDIES: EFFICACY AND DOSE-DEPENDENT EFFECTS}

A full listing of the 19 published human studies with D-serine is shown in Table 1. D-Serine has mainly been studied for schizophrenia and related psychotic disorders, but a role for use in tics disorder (61), movement disorders (58), alcohol dependence (64), dementia (65), post-traumatic syndrome disorder (56), and depression $(66,67)$ have also been proposed and studied.

D-Serine was originally reported to be beneficial in schizophrenia based upon studies conducted in Taiwan (52) and Israel (54). A recent meta-analysis of NMDAR modulators in 
TABLE 1 | Renal safety of D-serine.

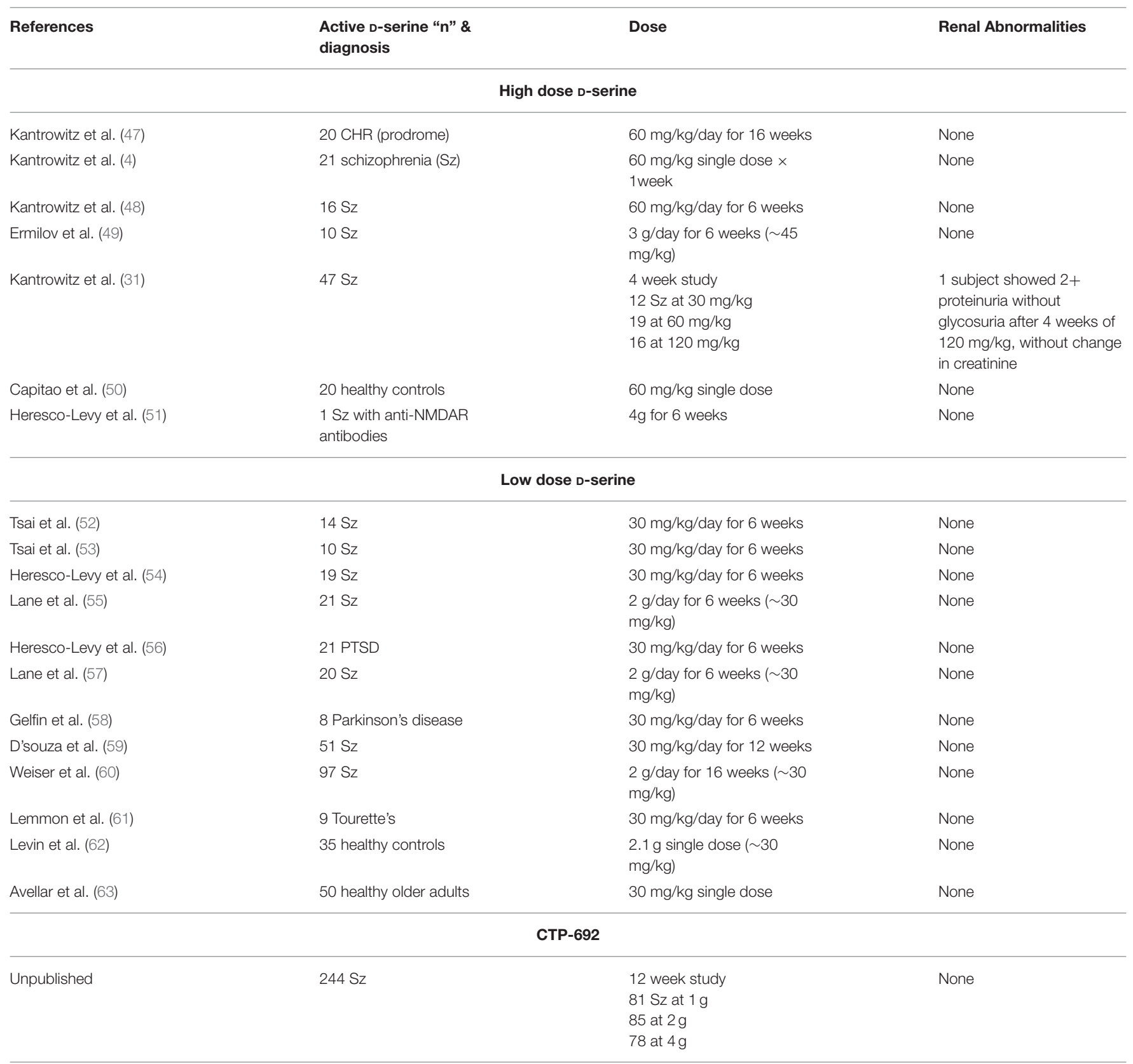

schizophrenia (3) has found specific improvement for D-serine adjunctive to antipsychotics for negative symptoms measured by both the Scale for the Assessment of Negative Symptoms (SANS) (68), with a standardized mean difference (SMD) $=-0.56$ and the Positive and Negative Symptom Scale (PANSS) negative symptom subscale (69), with a SMD of -0.49 . The meta-analysis for D-serine for total PANSS symptoms was not significant (SMD $=-0.3$ ). Of note, while a positive trial of the closely related compound D-alanine (70) was included in the meta-analysis, it was not grouped with D-serine as we have done in the past (48). D-Serine's utility as a cognitive enhancer was not evaluated in this meta-analysis.
The majority of human D-serine studies have used a low (30 $\mathrm{mg} / \mathrm{kg}, \sim 2 \mathrm{~g} /$ day) dosage, with a significant, but small effect size improvement (SMD $=-0.32$ ) at this dose in meta-analyses (46). This provides proof of concept, but suggests $30 \mathrm{mg} / \mathrm{kg}$ may be inadequate to fully engage the NMDAR, as evidenced by larger multi-center studies of $30 \mathrm{mg} / \mathrm{kg}$ which failed to separate from placebo $(59,60)$.

Pre-clinical studies suggest the need for higher doses. As further discussed in the Renal effects of D-serine section, rats are especially, and possibly uniquely vulnerable to D-serine induced nephrotoxicity. Thus, pre-clinical behavioral studies need to be completed in mice. In mice, effective doses of $\mathrm{D}$-serine have been 
in the range of $600-1,000 \mathrm{mg} / \mathrm{kg}$, roughly equivalent to human doses $>30 \mathrm{mg} / \mathrm{kg}(60-120 \mathrm{mg} / \mathrm{kg})(71)$. In other assay systems, numerical reversal of NMDAR antagonist induced (MK-801induced) hyperactivity in mice was observed at a dose of 600 $\mathrm{mg} / \mathrm{kg}$, although significant reduction was not observed until $4,000 \mathrm{mg} / \mathrm{kg}(72)$.

Human studies have supported the safety and efficacy of higher dose $\mathrm{D}$-serine, defined as $\geq 60 \mathrm{mg} / \mathrm{kg}, \geq 4 \mathrm{~g} /$ day. An open label dose finding study compared cohorts of 30,60, and $120 \mathrm{mg} / \mathrm{kg} / \mathrm{day}$, finding dose-dependent improvement (31). Significant improvement for total PANSS symptoms was seen at all doses, but specific improvement for both positive and negative symptoms individually was only seen in the $120 \mathrm{mg} / \mathrm{kg} / \mathrm{day}$ cohort. Similarly, a dose-dependent effect for cognition was seen, finding significantly greater improvement at $\geq 60 \mathrm{mg} / \mathrm{kg}$ vs. Thirty milligram/kilogram dose for the Measurement and Treatment Research to Improve Cognition in Schizophrenia (MCCB) (73) composite $(p=0.017)$. A pharmacodynamic analysis supported a dose effect, finding that higher peak serum levels of D-serine predict greater MCCB scores and improvement on the PANSS in this study, consistent with studies suggesting that basal serum levels of $\mathrm{D}$-serine are related to cognition $(74,75)$.

The initial double blind studies of high dose D-serine were conducted at a dose of $60 \mathrm{mg} / \mathrm{kg}$, due to caution after a single subject with abnormal renal values at $120 \mathrm{mg} / \mathrm{kg}$ (31), as further discussed in the Renal effects of D-serine section. A doubleblind high dose study in schizophrenia showed significant, large effect size improvements for both total (Cohen's $d=$ $0.8)$ and negative symptoms $(d=0.88)$ (48). Additionally, a nonsignificant, moderate effect size improvement was seen for the MCCB composite $(d=0.41)$ and significant target engagement was seen using mismatch negativity. A high dose study in a clinically high risk (CHR) for schizophrenia group (47) also showed significant improvement in prodromal negative symptoms $(d=0.68)$. Meta-analysis including high dose studies demonstrate moderate to large effect sizes for negative symptoms $(3,48)$, improving on meta-analysis that only include low dose studies (46).

D-serine as an adjunct to cognitive remediation has been also been proposed $(39,76,77)$. One trial used daily low dose D-serine without evidence of efficacy (59), but a trial of $60 \mathrm{mg} / \mathrm{kg}$ using an intermittent (once weekly) strategy has shown promising results (4). An ongoing double-blind dose finding study is assessing D-serine doses up to $120 \mathrm{mg} / \mathrm{kg}$ (10), using an intermittent dose strategy.

Further evidence for the necessity of testing higher doses of $\mathrm{D}$-serine and related compounds come from the recent negative study of CTP-692 which is a deuterated form of D-serine that reportedly has both less potential renal toxicity and a longer $t^{1 / 2}$ (78). In this publicly reported, but not published study, fixed CTP-692 doses were used, and the highest tested dose was $4 \mathrm{~g}$. Based on publicly available mean weight in $\mathrm{kg}$ per dose groups, the highest dose of CTP-692 tested were equivalent to $\sim 45 \mathrm{mg} / \mathrm{kg}$ on average (https://ir.concertpharma.com/news-releases/newsrelease-details/concert-pharmaceuticals-announces-results- ctp-692-phase-2-trial). Thus, even the highest tested doses of CTP-692 may have been too low, which may have contributed to the negative study.

\section{RENAL EFFECTS OF D-SERINE}

In addition to their importance in the brain, NMDAR are found throughout the body, including the kidney, where they play a diverse, if not fully elucidated role (79-81). D-Serine is also found in the kidney, with a potential physiological role (80).

The potential risk of $\mathrm{D}$-serine induced nephrotoxicity has been described since the 1940's (82-84), primarily based on studies in rats, and classically leads to a reversible acute necrosis, termed acute tubular necrosis. Pathological changes are present within 1 to $2 \mathrm{~h}$ post $\mathrm{D}$-serine administration, and are generally limited to necrotic changes of the straight segment of the proximal tubule (85-87), which is the primary site of D-serine reabsorption (88). The earliest changes are pronounced eosinophilia in the straight proximal tubules (87). Concurrently, acute increases in urine volume, glucosuria, proteinuria, and aminoaciduria, including Dserine are seen $(85,86)$, while sodium and potassium excretion remains stable. D-Serine excretion peaks within the first $8 \mathrm{~h}$ post dose (87). Other specific findings include granular (muddy) casts seen on urinalysis.

Despite these acute pathological changes, D-serine induced nephrotoxicity appears to be fully reversible (85), even in rats. Urine values of protein, glucose and amino acids begin to normalize $24-48 \mathrm{~h}$ after the last dose of $\mathrm{D}$-serine and by $120 \mathrm{~h}$ post dose, largely return to normal (87). Pathological changes also completely resolve within this timeframe, with complete regrowth of new epithelium in tubules and renal tubular basophilia (87).

In addition to being reversible, D-serine induced nephrotoxicity has only been observed in rats. In other species, including other rodents, D-serine induced nephrotoxicity has not been reported. Tested species include guinea pigs, rabbits, and mice (84), along with dogs, hamsters, and gerbils (89). Most importantly for the treatment of psychiatric disease in humans, is the lack of evidence for D-serine induced nephrotoxicity in humans (Table 1). Even in rats, this heightened risk to D-serine does not appear to occur during "normal," physiological levels of D-serine.

The etiology for the isolated risk to rats as compared to other species is not completely clear, but appears to be due to both higher reabsorption of $\mathrm{D}$-serine by rat kidneys compared to other species and differences in DAAO function. The presence of enhanced reabsorption is apparent from the low levels of D-serine in rat urine relative to that of other species, such humans and dogs, despite relatively similar serum levels (90). Moreover, nephrotoxicity during exogenous D-serine administration may be related to oxidative stress from the increased DAAO breakdown of D-serine $(29,91-93)$. DAAO is localized in pars recta of the kidney, where D-serine (94, $95)$ is primarily reabsorbed and the focal point of damage during D-serine nephrotoxicity. While levels of DAAO in rats do not appear to be quantitatively different than in other 
species (96), rat DAAO may be less efficient, which may compound the risk of nephrotoxicity due to hyperfunction during periods of excess D-serine (97). Relatedly, reducing DAAO activity through DAAO knockouts or concurrent DAAO inhibitors may be nephroprotective to excess D-serine (see DAAO clinical and safety section). Finally, studies also suggest that rats may have a higher capacity of utilizing D-amino acids (29) and that NMDAR may be directly involved in producing nephrotoxicity (98).

By contrast to rats, in most other species, including humans, D-serine is not actively reabsorbed $(90,99,100)$, as evidenced by relatively higher $\mathrm{D}$-serine urine levels in humans compared to rats of D-serine under physiological conditions (90). In humans, D-serine does not accumulate in serum under physiologic conditions, other than in people $(101,102)$ or mice (103) with pre-existing renal impairment. Under these pathological conditions, D-serine may be a biomarker of renal disease or recovery in humans (104-107), rising or falling in proportion to creatinine. However, there does not appear to be a causal link between $\mathrm{D}$-serine and renal impairment.

Even in rats, D-serine nephrotoxicity appears to be dose related. The initial rat toxicity studies used doses of 750-1,000 $\mathrm{mg} / \mathrm{kg}(83,85,86)$, and in doses $\geq 500 \mathrm{mg} / \mathrm{kg}$, nephrotoxicity after $\mathrm{D}$-serine treatment appears to be very common, if not universal in rats. Similar to mice (71), however, the oral dose to serum concentration ratio does not appear to follow a 1:1 ratio in rats compared to humans, complicating direct translational studies.

Recently, the pharmacokinetics and toxicokinetics of Dserine in rats was systematically studied (108), potentially allowing for a more direct rat to human comparison. In this study, five intraperitoneal doses were tested, 0.6, 1.2, 1.8, 2.4 , and $4.8 \mathrm{mmol} / \mathrm{kg}$. Based on an assumption of linear pharmacokinetics and a comparison with human studies (31), the $1.8 \mathrm{mmol} / \mathrm{kg}$ rat dose is thought to be approximately equivalent to an oral human dose of $450 \mathrm{mg} / \mathrm{kg}, \sim 3 \times$ the highest tested human dose. No nephrotoxicity was observed at either 6 or $24 \mathrm{~h}$ post dose at the 0.6 or $1.2 \mathrm{mmol} / \mathrm{kg}$ doses. Beginning at $1.8 \mathrm{mmol} / \mathrm{kg}$, significant dose dependent elevations are seen for urine protein and glucose compared to the $0.6 \mathrm{mmol} / \mathrm{kg}$ dose at $6 \mathrm{~h}$ and for serum creatine from baseline at $24 \mathrm{~h}$. Toxicity was also seen at higher doses (2.4 and $4.8 \mathrm{mmol} / \mathrm{kg})$.

A Cmax of $\sim 2,000 \mathrm{nmol} / \mathrm{mL}$ was the dividing line between safety and nephrotoxicity in this study, which was achieved with the $450 \mathrm{mg} / \mathrm{kg}$ equivalent dose $(1.8 \mathrm{mmol} / \mathrm{kg}$ ) (see Figure 1). Additional support for a dose response for toxicity in rats was shown in a study in which doses $\leq$ to $250 \mathrm{mg} / \mathrm{kg}$ were safe, while $500 \mathrm{mg} / \mathrm{kg}$ produced the expected nephrotoxicity (87). Other studies have reported toxicity at $400 \mathrm{mg} / \mathrm{kg}$ (92). For comparison, the single dose Cmax of $120 \mathrm{mg} / \mathrm{kg}$, the highest dose tested in humans, was $530.3 \pm 266.8 \mathrm{nmol} / \mathrm{mL}$ in acute dosing (31). After 4 weeks of chronic dosing, there was some accumulation, but the Cmax remained well-below 2,000 nmol/mL $(\sim 800$ $\mathrm{nmol} / \mathrm{mL}$ ). We are aware of one study suggesting that extremely large doses of $\mathrm{D}$-serine can induce nephrotoxicity in a cell culture of human renal tubular cells (109). However, this study used D-serine concentrations of 10 to $20 \mathrm{mM}$, which are 20 to 40 times greater than the Cmax of $120 \mathrm{mg} / \mathrm{kg}(0.5 \mathrm{mM}$ or $\sim 500 \mu \mathrm{M})$.

Nineteen human trials have been published or publicly presented with $\mathrm{D}$-serine or the closely related compound of CTP-692 (Table 1), including 490 subjects receiving D-serine with treatment durations ranging from single doses to 16 weeks of daily dosing and 244 patients on CTP-692. One hundred twenty-two subjects received high dose D-serine $(>30 \mathrm{mg} / \mathrm{kg})$, including 16 patients receiving $120 \mathrm{mg} / \mathrm{kg}$ for 4 weeks. SeventyEight subjects received high dose CTP-692, defined as $4 \mathrm{~g}$ per day. Across all studies, only one subject was reported to have abnormal renal values related to D-serine treatment (31). Overall, this 1 case represents $0.2 \%$ of all D-serine treated subjects, $<1 \%$ of subjects treated with daily high dose D-serine and one of 16 (6.3\%) of subjects treated with $120 \mathrm{mg} / \mathrm{kg}$ daily. Several mild out of range renal values were noted in the CHR study (47). No renal adverse effects were reported in the CTP-692 study.

The single abnormality at $120 \mathrm{mg} / \mathrm{kg}$ occurred in a subject after receiving 4 weeks of the $120 \mathrm{mg} / \mathrm{kg}$ dose. This abnormality was considered mild in that it involved only an increase in protein $(2+$ by dipstick) without granular casts or an accompanying increase in glycosuria, change in creatinine level or other clinical correlates of renal dysfunction, and fully resolved within a few days of stopping treatment. Thus, this abnormality does not clearly map on to the acute nephrotoxicity syndrome seen in rats. Under our current FDA approved safety monitoring criteria, fully described in the Recommendations for monitoring during clinical D-serine studies section, this abnormality would not have been considered a serious adverse event (SAE).

\section{D-SERINE AND THE PANCREAS AND METABOLISM}

Moving beyond the brain and the kidney, D-Serine may play a physiologic role in both appetite and insulin regulation in the pancreas, which is of potential clinical relevance since many antipsychotics are associated with clinically significant weight gain and metabolic disturbances $(110,111)$. D-Serine appears to be elevated in pre-clinical mice models of diabetes, but this seems to be an effect, and not a contributing cause of diabetes in vivo $(112,113)$. As recently reviewed $(114,115)$, functional NMDAR are found in pancreatic islets and $\beta$-cells, which regulate insulin release. The role of NMDAR in the pancreas is complex, with some studies suggesting that NMDAR antagonism would be therapeutic, and some suggesting the opposite. A similarly unclear role is found for D-serine itself, and D-serine has been studied both as a potential treatment for metabolic disorders and for adverse effects.

Part of the complexity and lack of clarity of the NMDAR and D-serine's role in glucose homeostasis stems from the varied dosages that were used in pre-clinical experiments. Under physiologic conditions, D-serine appears to activate pancreatic NMDAR to stimulate $\beta$-cell and potentiate insulin release (116). At higher, non-physiologic doses, D-serine may lead to toxicity due to NMDAR internalization, reducing $B$-cell activity, and reduced insulin release. Serine racemase is present and active in 


\section{4-hour pharmacokinetics of an acute dose of D-serine}

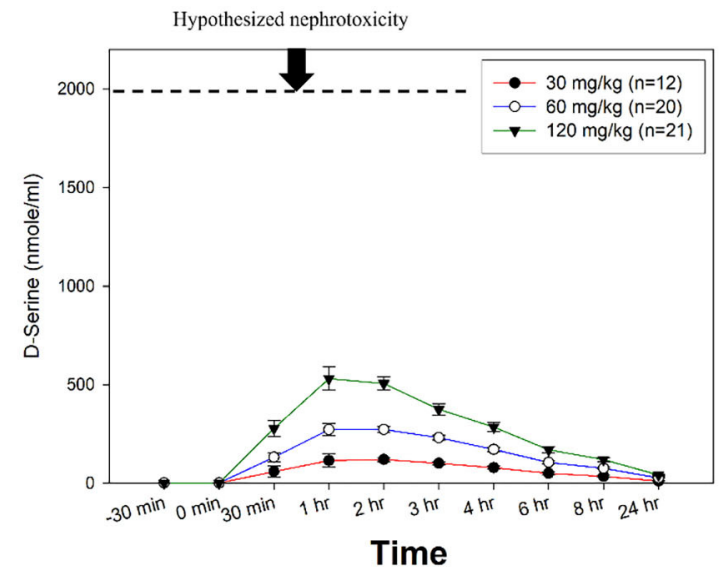

4-hour pharmacokinetics of after chronic D-serine

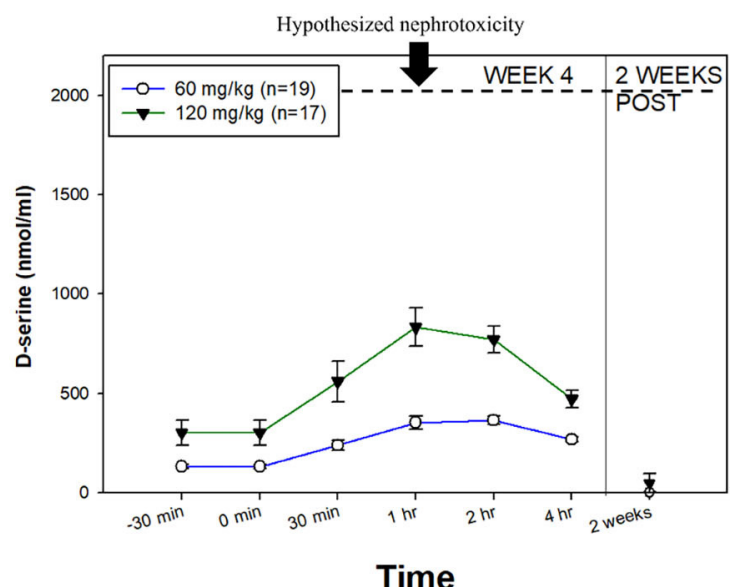

FIGURE 1 | D-serine Pharmacokinetics. (Left) 24-h pharmacokinetics of an acute dose of D-serine on day 1 of treatment. (Right) 4-h pharmacokinetics after 4 weeks of chronic dosing. In both figures, the hypothesized renal safety level is added based on experiments in rats. Modified from Kantrowitz et al. (31), Hasegawa et al. (108).

the pancreas (117), and helps regulate insulin secretion (118), further suggesting a role for D-serine. By contrast, a recent study (119) suggests that large doses chronic D-serine supplementation results in both reduced high fat diet intake and impaired insulin secretion in mice. In this study, mice received $10 \mathrm{~g}$ of $\mathrm{D}$ serine/L of water, and assuming a $25 \mathrm{~g}$ mouse drinks $5 \mathrm{~mL}$ of water/day (120), the doses required to impair insulin secretion were large $(\sim 2,000 \mathrm{mg} / \mathrm{kg})$, and thus may be of questionable clinical relevance.

Other studies $(121,122)$ have also supported a dose dependent role for D-serine suppressing intake of high preference (high-fat) food, suggesting potential utility in modulating obesity. In these studies, an appetite suppressant effect was seen at D-serine $>1.5$ $\mathrm{g} / \mathrm{kg}$ per day, but not at lower doses. The largest doses studied in humans are $\sim 10 \times$ smaller $(120 \mathrm{mg} / \mathrm{kg})$, limiting the translation of these findings to human studies.

Two recently published human studies assessing D-serine's role in monitoring diabetes have shown inconsistent results. Across one study with 96 women with gestational diabetes and 96 with normal glucose tolerance, serine was significantly higher in the gestational diabetes cohort (123). By contrast, in a separate study of 1,623 non-diabetic subjects (124), the opposite result was seen, as lower serine levels were predictive of impaired glucose tolerance. In both studies, we note that the term serine is used, and it is unclear if the measurements were of $\mathrm{D}$-serine, $\mathrm{L}$-serine or a combination. In published studies, no clinically relevant weight gain or metabolic alterations have been reported in clinical studies of D-serine (Table 2).

\section{D-SERINE AND THE ENDOCRINE SYSTEM}

Aside from the brain, the kidney and the pancreas, D-serine has been most thoroughly studied in endocrine systems. As recently reviewed (17), D-serine is detected in vivo in multiple endocrine glands, including the hypothalamus, pituitary, pineal,
TABLE 2 | Adverse events reported in d-serine trials ${ }^{a}$.

\begin{tabular}{lcccc}
\hline Adverse event & Total $\boldsymbol{n}$ & $\begin{array}{c}\text { D-serine } \\
\text { (\%) }\end{array}$ & $\begin{array}{c}\text { Placebo } \\
\text { (\%) }\end{array}$ & $\begin{array}{c}\text { Risk ratio (95\% Cl); } \\
\boldsymbol{p} \text {-value }\end{array}$ \\
\hline Abdominal discomfort & 31 & 0 & 5.9 & $0.40(0.02,9.12) ; 0.57$ \\
Anxiety & 84 & 4.9 & 9.3 & $0.52(0.10,2.70) ; 0.44$ \\
Constipation & 115 & 7.3 & 0 & $3.93(0.66,23.25) ; 0.13$ \\
Depression & 44 & 4.8 & 4.3 & $1.10(0.07,16.43) ; 0.95$ \\
Diarrhea & 31 & 7.1 & 0 & $3.60(0.16,82.05) ; 0.42$ \\
Dizziness & 192 & 15.8 & 26.5 & $0.61(0.32,1.18) ; 0.14$ \\
Dry mouth & 149 & 5.4 & 0 & $9.12(0.50,166.46) ; 0.14$ \\
Fatigability & 84 & 22.0 & 23.2 & $0.96(0.19,4.74) ; 0.96$ \\
Headache & 149 & 17.6 & 38.7 & $0.45(0.26,0.80) ; 0.007$ \\
Nausea & 31 & 14.3 & 0 & $6.00(0.31,115.56) ; 0.24$ \\
Palpitation & 84 & 29.3 & 27.9 & $1.06(0.45,2.48) ; 0.89$ \\
Salivation & 44 & 14.3 & 8.7 & $1.64(0.30,8.89) ; 0.56$ \\
Sexual dysfunction & 26 & 7.7 & 0 & $3.00(0.13,67.51) ; 0.49$ \\
Sleep disturbance & 115 & 21.8 & 20 & $1.07(0.53,2.18) ; 0.85$ \\
Weight gain & 84 & 43.9 & 44.2 & $1.05(0.69,1.59) ; 0.81$ \\
Weight loss & 84 & 7.3 & 4.7 & $1.36(0.16,11.68) ; 0.78$
\end{tabular}

aModified from Goh (3).

thyroid, adrenals, ovary, and testes. However, levels of D-serine in the endocrine organs are lower than those in the CNS, and the physiological role of $\mathrm{D}$-serine in most endocrine organs is unclear.

A role for a regulation of sleep has been reported for both glycine and D-serine, following up on small clinical studies of glycine (125). In a pre-clinical study, improved sleep was seen with direct injection of either glycine or D-serine into the suprachiasmatic nucleus of the hypothalamus (126). DSerine may also be involved in activating the NMDAR in 
the corpus cavernosum, suggesting a possible role in treating impotence (127).

\section{D-SERINE AND EXTRAPYRAMIDAL EFFECTS}

Antipsychotics are associated with varying levels of extrapyramidal motor side-effects (EPS) (110), such as Parkinson's like motor disturbances, tremor and dystonia. While one of the clearest advantages of many second generation antipsychotics is a relatively reduced incidence of EPS and other movement disorders such as tardive dyskinesia (TD) (128), both remain a clinically significant issue for many schizophrenia patients.

Antipsychotics likely cause EPS via dopamine type 2 receptor blockade in the striatum. In a pre-clinical mouse study (129), both $\mathrm{D}$-serine $(300 \mathrm{mg} / \mathrm{kg})$ and sodium benzoate $(600 \mathrm{mg} / \mathrm{kg})$ administered intraperitoneally attenuated haloperidol induced bradykinesia. D-serine showed a $U$-shaped curve for attenuation, as no effects were seen for 100 or $1,000 \mathrm{mg} / \mathrm{kg}$ doses. Our preclinical studies with mice (71), suggest a comparable mice dose of approximately $100 \mathrm{mg} / \mathrm{kg}$ for the $60 \mathrm{mg} / \mathrm{kg}$ clinical dose. In this study, D-cycloserine, which acts as an agonist at the Dserine/glycine site of the NMDAR, but a ketamine like antagonist at higher doses (130-132), also attenuated haloperidol induced bradykinesia at doses up to $30 \mathrm{mg} / \mathrm{kg}$, which likely is in the NMDAR agonist range.

Two clinical studies with D-serine have suggested improvement in antipsychotic induced EPS and/or TD in schizophrenia patients $(31,54)$. One small study of 8 patients suggested efficacy of low dose D-serine for both the behavioral and motor symptoms of Parkinson's disease (58). A double blind study of high dose D-serine did not find a significant benefit for EPS (48).

Amyotrophic lateral sclerosis (ALS) is a fatal neurodegenerative disorder involving an extensive loss of motor neurons, and some familial and sporadic cases have been associated with D-serine metabolism. Specifically, mutations of DAAO have been reported (133), which are associated with pre-clinical and clinical increases of D-serine $(30,134)$. One recent study found elevated plasma levels of D-serine in $\sim 40 \%$ of ALS patients compared to healthy controls (135). Based on publicly presented, but unpublished observations in studies conducted to support our IND, there is no evidence of D-serine accumulation in motor neurons (71), and there has been no evidence of motor adverse events in human studies.

\section{D-SERINE, THE LIVER AND THE GASTROINTESTINAL TRACT}

D-Serine is cleared almost exclusively by the kidney, and is not metabolized by hepatic P450 enzymes. DAAO is present in the liver, and may contribute to D-serine degradation (136). The pre-clinical literature of D-serine's effects on the liver are sparse, but early experiments did not find evidence of a $\mathrm{D}$ serine specific hepatoxic effect in rats using known nephrotoxic doses $(1,000 \mathrm{mg} / \mathrm{kg})(83)$. One study using extremely large doses of D-serine $(20 \mathrm{mM})$ was hepatotoxic to in vitro rat liver cells and mitochondria, producing oxidative stress and swelling (137). In clinical studies, mild, asymptomatic transaminitis has been reported in two subjects receiving daily $120 \mathrm{mg} / \mathrm{kg}$ (31). Only one of the subjects had liver function tests (LFTs) $>2 \times$ upper normal range. This mild transaminitis resolved completely after D-serine discontinuation for both patients, and may have been related to the recent administration of the hepatitis vaccine in the patient with the larger elevations, which in rare cases can give rise to elevated liver enzymes (http://vaers.hhs.gov).

In mice, D-serine has shown promise as a treatment and prophylaxis for inflammatory bowel disease (138), albeit at high doses, $>1.5 \mathrm{~g} / \mathrm{kg}$ per day. Finally, D-serine may be involved in lower esophageal sphincter contraction (139), with unclear clinical relevance. D-Serine has not been associated with elevated rates of gastrointestinal adverse events in clinical studies (Table 2).

\section{D-SERINE AND THE CARDIOVASCULAR SYSTEM}

As recently reviewed, NMDAR are also present in cardiac and vascular tissue (140), and activation of these peripheral NMDAR in vitro can lead to tachycardia and hypertension (141). While there is no known physiologic role for D-serine in the heart, D-serine could theoretically lead to increased cardiovascular tone by activating NMDAR. By contrast, the NMDAR antagonist ketamine, consistently produces tachycardia and hypertension in clinical studies (1). While direct application of ketamine on in vitro cardiac tissue induces bradycardia (142), the tachycardic/hypertensive effects of in vivo ketamine are mediated through brain, with evidence for both centrally mediated top-down control (143-145) and direct effects on the baroreflex in the nucleus tractus solitarii (NTS) in the brainstem (medulla) (146-149). No clinically relevant cardiovascular effects have been reported in clinical studies of $\mathrm{D}$-serine.

\section{D-SERINE AND CANCER}

As recently reviewed (150), D-amino acids may be elevated in some cancers. D-Serine does not appear to be a causal factor in tumorigenesis, but there may be increased reuptake of D-serine by some cancer cells, particularly in high glucose environments (151). Alternatively, D-amino acids may be useful for the treatment of some cancers (152-154).

\section{DAAO INHIBITOR CLINICAL STUDIES AND SAFETY}

DAAO-inhibitors have been proposed as a treatment for schizophrenia, functioning in a similar way to a selective serotonin reuptake inhibitor (SSRI) by increasing $\mathrm{D}$-serine levels indirectly. Several DAAO-inhibitors are in development, including luvadaxistat and sodium benzoate. Sodium benzoate 
has shown efficacy in several, but not all published studies (155158), and is being actively developed by SyneuRx International (NCT02261519). Luvadaxistat is under development by a partnership between Takeda and Neurocrine (159), and showed preliminary efficacy for cognitive outcomes in publicly presented, but unpublished results.

Although DAAO-inhibitors raise the levels of D-serine and increased DAAO activity may be contributory to nephrotoxicity in rats (91-93), pre-clinical studies suggest that DAAO-inhibitors may protect against D-serine induced nephrotoxicity $(29,160)$. In a study of rats without functional DAAO activity, D-serine $800 \mathrm{mg} / \mathrm{kg}$ did not cause renal damage (29). Furthermore, administration of D-propargylglycine, which is known to cause nephrotoxicity through DAAO (161), also did not cause renal damage in the DAAO knockout rats. By contrast, both D-serine and D-propargylglycine led to the expected nephrotoxicity in the control rats with normal DAAO.

Direct evidence that DAAO-inhibitors are nephroprotective has also been demonstrated in rats (160). In this study, rats were given D-serine $500 \mathrm{mg} / \mathrm{kg} 1 \mathrm{~h}$ after receiving one of 4 doses of sodium benzoate $(125,250,500$, or $750 \mathrm{mg} / \mathrm{kg})$. A dose dependent nephroprotective effect was seen with pretreatment with sodium benzoate $500 \mathrm{mg} / \mathrm{kg}$ or greater. The protective effects were most apparent in the first urinalysis samples several hours after D-serine. Pathological samples after $24 \mathrm{~h}$ with and without sodium benzoate showed nephrotoxic changes, but sodium benzoate appeared to attenuate these changes as compared to the D-serine alone samples. There has been no reported renal toxicity reported in clinical studies of DAAOinhibitors. Taken together, these studies support the safety of potential combined D-serine + DAAO-inhibitor studies, which have shown promise pre-clinically (162-164).

\section{ADVERSE EVENTS IN CLINICAL STUDIES OF D-SERINE}

In Table 2, we present a summary of adverse events in published trials of D-serine, modified from a similar table in a meta-analysis of NMDAR trials in schizophrenia (3). As in the meta-analysis, the present report uses the total of all subjects in which an adverse event is reported as the total potentially affected, rather than the total number in all studies. This allows for a more conservative estimate of the rates of an adverse event. The downside to the analysis is that adverse events were not systematically reported in most of these studies, and the overall $\mathrm{n}$ is small. Noting these caveats, in these studies, the only adverse event reported at a significantly different rate than placebo is headache, finding a significantly lower rate of headaches in the of D-serine group.

\section{RECOMMENDATIONS FOR MONITORING DURING CLINICAL D-SERINE STUDIES}

In our FDA-monitored studies, we monitor for safety as follows. Routine safety laboratory measures, including a chemistry with serum creatinine and LFTs, a complete blood count and a urinalysis with microscopics, are obtained at screening. Vitals and ECGs are also obtained. No subjects with baseline renal impairment, as evidenced by an estimated glomerular filtration rate $(\mathrm{eGFR})<60$ or clinically significant abnormal laboratories are enrolled.

During the study, potential nephrotoxicity is monitored through serum chemistry and urine microscopic examination looking for evidence of active sediment (e.g., casts), proteinuria or glycosuria, as per FDA guidance.

After randomization, we monitor as follows:

(a) Urinalysis with microscopics and chemistry biweekly for daily studies or after each dose for intermittent treatment.

(b) Immediately discontinue $\mathrm{D}$-serine for unexplained serum creatinine increase $>0.3 \mathrm{mg} / \mathrm{dL}$ over the pre-study value or for $>1$ granular or muddy casts. Treat as SAE possibly related to study medication. Repeat until clear $\times 2$ to demonstrate reversibility.

(c) Hold D-serine for $>1$ hyaline casts, and repeat lab. Ask subject to eat more salt and drink more water. If absent on repeat, reinstate $\mathrm{D}$-serine and treat as adverse event (AE). If present on repeat, continue to hold $\mathrm{D}$-serine and repeat lab once again. If still present on second repeat, discontinue Dserine and treat as SAE possibly related to study medication. Repeat until clear $\times 2$ to demonstrate reversibility.

(d) Hold D-serine for proteinuria $>100 \mathrm{mg} / \mathrm{dl}$ or unexplained glucose $>250 \mathrm{~g} / \mathrm{dl}$ (both equivalent to $2+$ ). If absent on repeat, resume $\mathrm{D}$-serine and treat as $\mathrm{AE}$. If still present on repeat, discontinue $\mathrm{D}$-serine. Repeat until clear $\mathrm{x} 2$ to demonstrate reversibility. This would be treated as SAE possibly related to study medication. Unexplained glycosuria is defined as increased urine glucose in absence of corresponding increase in serum glucose levels, in patients without glycosuria at baseline.

(e) Continue D-serine for proteinuria $>30$ but $<100 \mathrm{mg} / \mathrm{dl}(1+)$, or unexplained glycosuria ( $>100$ but $<250 \mathrm{~g} / \mathrm{dl}$ ) but repeat. If absent on repeat, continue $\mathrm{D}$-serine and treat as $\mathrm{AE}$. If still present on repeat, hold $\mathrm{D}$-serine and repeat once more. If absent on repeat, resume $\mathrm{D}$-serine and treat as AE. If still present on second repeat, discontinue $\mathrm{D}$-serine and treat as SAE possibly related to study medication. Repeat until clear $\times 2$ to demonstrate reversibility.

(f) For other kidney related measures (e.g., ketones, bilirubin, WBC, RBC, bacteria, crystals), repeat, but no need to discontinue even if present on repeat, since unlikely to be $\mathrm{D}$-serine related. Manage in consultation with medical specialist.

(g) Contaminated samples (hemolyzed/non-clean catch/menstruation) will be repeated.

\section{CONCLUSIONS}

Schizophrenia remains a difficult to treat illness, with a large majority of patients not responding completely to FDA approved antipsychotics. D-Serine appears efficacious in schizophrenia, especially in high doses $(\geq 60 \mathrm{mg} / \mathrm{kg})$. Our literature review supports that $\mathrm{D}$-serine is safe and well-tolerated in people without pre-existing renal dysfunction. While there is no evidence of 
D-serine being nephrotoxic in humans, we require that people with pre-existing renal dysfunction $(\mathrm{GFR}<60)$ be excluded from clinical studies.

Thus far, $120 \mathrm{mg} / \mathrm{kg}$ is the highest $\mathrm{D}$-serine dose tested in human studies, but animal studies suggest that even higher doses may be required for optimal target engagement. In this review, we have taken a conservative approach to interspecies dose equivalences, but note that standard mouse to human conversions of 12.3 to 1 have been proposed in the literature (165). Nevertheless, even before considering human to rodent differences in physiology, the literature supports that D-serine has potential safety at doses even higher than $120 \mathrm{mg} / \mathrm{kg}$. Ongoing dose-response studies are assessing the safety and efficacy of doses up to $120 \mathrm{mg} / \mathrm{kg}$, and future work is needed to explore

\section{REFERENCES}

1. Kantrowitz JT, Grinband J, Goff DC, Lahti AC, Marder SR, Kegeles LS, et al. Proof of mechanism and target engagement of glutamatergic drugs for the treatment of schizophrenia: RCTs of pomaglumetad and TS-134 on ketamine-induced psychotic symptoms and pharmacoBOLD in healthy volunteers. Neuropsychopharmacology. (2020) 45:1842-50. doi: 10.1038/s41386-020-0706-z

2. Potkin SG, Kane JM, Correll CU, Lindenmayer JP, Agid O, Marder SR, et al. The neurobiology of treatment-resistant schizophrenia: paths to antipsychotic resistance and a roadmap for future research. NPJ Schizophr. (2020) 6:1. doi: 10.1038/s41537-019-0090-z

3. Goh KK, Wu TH, Chen CH, Lu ML. Efficacy of N-methyl-D-aspartate receptor modulator augmentation in schizophrenia: a meta-analysis of randomised, placebo-controlled trials. J Psychopharmacol. (2021) 35:23652. doi: 10.1177/0269881120965937

4. Kantrowitz JT, Epstein ML, Beggel O, Rohrig S, Lehrfeld JM, Revheim N, et al. Neurophysiological mechanisms of cortical plasticity impairments in schizophrenia and modulation by the NMDA receptor agonist D-serine. Brain. (2016) 139:3281-95. doi: 10.1093/brain/aww262

5. Fleischhacker WW, Podhorna J, Groschl M, Hake S, Zhao Y, Huang $S$, et al. Efficacy and safety of the novel glycine transporter inhibitor BI 425809 once daily in patients with schizophrenia: a double-blind, randomised, placebo-controlled phase 2 study. Lancet Psychiatry. (2021) 8:191-201. doi: 10.1016/S2215-0366(20)30513-7

6. Bugarski-Kirola D, Iwata N, Sameljak S, Reid C, Blaettler T, Millar L, et al. Efficacy and safety of adjunctive bitopertin versus placebo in patients with suboptimally controlled symptoms of schizophrenia treated with antipsychotics: results from three phase 3, randomised, double-blind, parallel-group, placebo-controlled, multicentre studies in the SearchLyte clinical trial programme. Lancet Psychiatry. (2016) 3:111528. doi: 10.1016/S2215-0366(16)30344-3

7. Dunayevich E, Buchanan RW, Chen CY, Yang J, Nilsen J, Dietrich JM, et al. Efficacy and safety of the glycine transporter type-1 inhibitor AMG 747 for the treatment of negative symptoms associated with schizophrenia. Schizophr Res. (2017) 182:90-7. doi: 10.1016/j.schres.2016.10.027

8. Kantrowitz JT, Nolan KA, Epstein ML, Lehrfeld N, Shope C, Petkova E, et al. Neurophysiological effects of bitopertin in schizophrenia. $J$ Clin Psychopharmacol. (2017) 37:447-51. doi: 10.1097/JCP.0000000000 000722

9. Grabb MC, Cross AJ, Potter WZ, Mccracken JT. Derisking psychiatric drug development: the NIMH's fast fail program, a novel precompetitive model. J Clin Psychopharmacol. (2016) 36:419-21. doi: 10.1097/JCP.0000000000000536

10. De La Garrigue N, Glasser J, Sehatpour P, Iosifescu DV, Dias E, Carlson M, et al. Grant report on D-serine augmentation of neuroplasticity-based auditory learning in schizophrenia (dagger). J Psychiatr Brain Sci. (2020) 5:e200018. doi: 10.20900/jpbs.20200018 the possibility of even higher doses or combined D-serine + DAAO-inhibitor studies.

\section{AUTHOR CONTRIBUTIONS}

JK and AM: substantial contributions to conception and design. $\mathrm{JK}, \mathrm{AM}$, and $\mathrm{HH}$ : drafting of the manuscript and critical revision of the manuscript for important intellectual content. All authors reviewed the final submission and gave final approval of the submitted version.

\section{FUNDING}

This work was supported by R61 MH116093 to JK.

11. Kantrowitz JT, Javitt DC. Glutamatergic approaches to the conceptualization and treatment of schizophrenia. In: Javitt DC, Kantrowitz JT, editors. Handbook of Neurochemistry and Molecular Neurobiology. 3rd edn. New York, NY: Springer (2009). doi: 10.1007/978-0-387-30410-6_3

12. Kantrowitz JT, Javitt DC. N-methyl-d-aspartate (NMDA) receptor dysfunction or dysregulation: the final common pathway on the road to schizophrenia? Brain Res Bull. (2010) 83:108-21. doi: 10.1016/j.brainresbull.2010.04.006

13. Hashimoto A, Nishikawa T, Hayashi T, Fujii N, Harada K, Oka T, et al. The presence of free D-serine in rat brain. FEBS Lett. (1992) 296:336. doi: 10.1016/0014-5793(92)80397-Y

14. Schell MJ, Molliver ME, Snyder SH. D-serine, an endogenous synaptic modulator: localization to astrocytes and glutamate-stimulated release. Proc Natl Acad Sci USA. (1995) 92:3948-52. doi: 10.1073/pnas.92.9.3948

15. Balu DT, Li Y, Puhl MD, Benneyworth MA, Basu AC, Takagi S, et al. Multiple risk pathways for schizophrenia converge in serine racemase knockout mice, a mouse model of NMDA receptor hypofunction. Proc Natl Acad Sci USA. (2013) 110:E2400-9. doi: 10.1073/pnas.1304308110

16. Balu DT, Coyle JT. The NMDA receptor 'glycine modulatory site' in schizophrenia: D-serine, glycine, and beyond. Curr Opin Pharmacol. (2015) 20:109-15. doi: 10.1016/j.coph.2014.12.004

17. Chieffi Baccari G, Falvo S, Santillo A, Di Giacomo Russo F, Di Fiore MM. D-Amino acids in mammalian endocrine tissues. Amino Acids. (2020) 52:1263-73. doi: 10.1007/s00726-020-02892-7

18. Dunlop DS, Neidle A. The origin and turnover of D-serine in brain. Biochem Biophys Res Commun. (1997) 235:26-30. doi: 10.1006/bbrc.1997.6724

19. Wolosker H, Sheth KN, Takahashi M, Mothet JP, Brady RO Jr, Ferris CD, et al. Purification of serine racemase: biosynthesis of the neuromodulator Dserine. Proc Natl Acad Sci USA. (1999) 96:721-5. doi: 10.1073/pnas.96.2.721

20. Foltyn VN, Bendikov I, De Miranda J, Panizzutti R, Dumin E, Shleper M, et al. Serine racemase modulates intracellular D-serine levels through an alpha,beta-elimination activity. J Biol Chem. (2005) 280:175463. doi: 10.1074/jbc.M405726200

21. Horiike K, Tojo H, Arai R, Nozaki M, Maeda T. D-amino-acid oxidase is confined to the lower brain stem and cerebellum in rat brain: regional differentiation of astrocytes. Brain Res. (1994) 652:297303. doi: 10.1016/0006-8993(94)90240-2

22. Moreno S, Nardacci R, Cimini A, Ceru MP. Immunocytochemical localization of D-amino acid oxidase in rat brain. J Neurocytol. (1999) 28:169-85. doi: 10.1023/A:1007064504007

23. Morikawa A, Hamase K, Inoue T, Konno R, Niwa A, Zaitsu K. Determination of free D-aspartic acid, D-serine and D-alanine in the brain of mutant mice lacking D-amino acid oxidase activity. J Chromatogr B Biomed Sci Appl. (2001) 757:119-25. doi: 10.1016/S0378-4347(01)00131-1

24. Miyoshi Y, Hamase K, Okamura T, Konno R, Kasai N, Tojo Y, et al. Simultaneous two-dimensional HPLC determination of free Dserine and D-alanine in the brain and periphery of mutant rats lacking D-amino-acid oxidase. J Chromatogr B Analyt Technol 
Biomed Life Sci. (2011) 879:3184-9. doi: 10.1016/j.jchromb.2010. 08.024

25. Strick CA, Li C, Scott L, Harvey B, Hajos M, Steyn SJ, et al. Modulation of NMDA receptor function by inhibition of D-amino acid oxidase in rodent brain. Neuropharmacology. (2011) 61:100115. doi: 10.1016/j.neuropharm.2011.06.029

26. Verrall L, Walker M, Rawlings N, Benzel I, Kew JN, Harrison PJ, et al. d-Amino acid oxidase and serine racemase in human brain: normal distribution and altered expression in schizophrenia. Eur J Neurosci. (2007) 26:1657-69. doi: 10.1111/j.1460-9568.2007.05769.x

27. Xia M, Liu Y, Figueroa DJ, Chiu CS, Wei N, Lawlor AM, et al. Characterization and localization of a human serine racemase. Brain Res Mol Brain Res. (2004) 125:96-104. doi: 10.1016/j.molbrainres.2004.03.007

28. Horio M, Kohno M, Fujita Y, Ishima T, Inoue R, Mori H, et al. Levels of Dserine in the brain and peripheral organs of serine racemase (Srr) knock-out mice. Neurochem Int. (2011) 59:853-9. doi: 10.1016/j.neuint.2011.08.017

29. Maekawa M, Okamura T, Kasai N, Hori Y, Summer KH, Konno R. Damino-acid oxidase is involved in D-serine-induced nephrotoxicity. Chem Res Toxicol. (2005) 18:1678-82. doi: 10.1021/tx0500326

30. Sasabe J, Miyoshi Y, Suzuki M, Mita M, Konno R, Matsuoka M, et al. Damino acid oxidase controls motoneuron degeneration through D-serine. Proc Natl Acad Sci USA. (2012) 109:627-32. doi: 10.1073/pnas.1114639109

31. Kantrowitz JT, Malhotra AK, Cornblatt B, Silipo G, Balla A, Suckow RF, et al. High dose D-serine in the treatment of schizophrenia. Schizophr Res. (2010) 121:125-30. doi: 10.1016/j.schres.2010.05.012

32. Takahashi K, Hayashi F, Nishikawa T. In vivo evidence for the link between L- and D-serine metabolism in rat cerebral cortex. J Neurochem. (1997) 69:1286-90. doi: 10.1046/j.1471-4159.1997.69031286.x

33. Pernot P, Maucler C, Tholance Y, Vasylieva N, Debilly G, Pollegioni L, et al. d-Serine diffusion through the blood-brain barrier: effect on Dserine compartmentalization and storage. Neurochem Int. (2012) 60:83745. doi: 10.1016/j.neuint.2012.03.008

34. Matsui T, Sekiguchi M, Hashimoto A, Tomita U, Nishikawa T, Wada $\mathrm{K}$. Functional comparison of D-serine and glycine in rodents: the effect on cloned NMDA receptors and the extracellular concentration. J Neurochem. (1995) 65:454-8. doi: 10.1046/j.1471-4159.1995.650 10454.x

35. Priestley T, Laughton P, Myers J, Le Bourdelles B, Kerby J, Whiting PJ. Pharmacological properties of recombinant human N-methyl-D-aspartate receptors comprising NR1a/NR2A and NR1a/NR2B subunit assemblies expressed in permanently transfected mouse fibroblast cells. Mol Pharmacol. (1995) 48:841-8.

36. Berger AJ, Dieudonne S, Ascher P. Glycine uptake governs glycine site occupancy at NMDA receptors of excitatory synapses. J Neurophysiol. (1998) 80:3336-40. doi: 10.1152/jn.1998.80.6.3336

37. Mothet JP, Parent AT, Wolosker H, Brady RO Jr, Linden DJ. D-serine is an endogenous ligand for the glycine site of the $\mathrm{N}$-methyl-D- aspartate receptor. Proc Natl Acad Sci USA. (2000) 97:4926-31. doi: 10.1073/pnas.97.9.4926

38. Otte DM, Barcena De Arellano ML, Bilkei-Gorzo A, Albayram O, Imbeault $\mathrm{S}$, Jeung $\mathrm{H}$, et al. Effects of chronic D-serine elevation on animal models of depression and anxiety-related behavior. PLoS ONE. (2013) 8:e67131. doi: 10.1371/journal.pone.0067131

39. Guercio GD, Panizzutti R. Potential and challenges for the clinical use of D-Serine as a cognitive enhancer. Front Psychiatry. (2018) 9:14. doi: 10.3389/fpsyt.2018.00014

40. Watanabe $\mathrm{Y}$, Saito H, Abe K. Effects of glycine and structurally related amino acids on generation of long-term potentiation in rat hippocampal slices. Eur J Pharmacol. (1992) 223:179-84. doi: 10.1016/0014-2999(92)94837-L

41. Hunt DL, Castillo PE. Synaptic plasticity of NMDA receptors: mechanisms and functional implications. Curr Opin Neurobiol. (2012) 22:496-508. doi: 10.1016/j.conb.2012.01.007

42. Luscher C, Malenka RC. NMDA receptor-dependent long-term potentiation and long-term depression (LTP/LTD). Cold Spring Harb Perspect Biol. (2012) 4:a005710. doi: 10.1101/cshperspect.a005710

43. Van Horn MR, Sild M, Ruthazer ES. D-serine as a gliotransmitter and its roles in brain development and disease. Front Cell Neurosci. (2013) 7:39. doi: $10.3389 /$ fncel.2013.00039
44. Ivanov $\mathrm{AD}$, Mothet JP. The plastic D-serine signaling pathway: sliding from neurons to glia and vice-versa. Neurosci Lett. (2019) 689:215. doi: 10.1016/j.neulet.2018.05.039

45. Diniz LP, Almeida JC, Tortelli V, Vargas Lopes C, Setti-Perdigao P, Stipursky J, et al. Astrocyte-induced synaptogenesis is mediated by transforming growth factor beta signaling through modulation of Dserine levels in cerebral cortex neurons. J Biol Chem. (2012) 287:4143245. doi: 10.1074/jbc.M112.380824

46. Cho SE, Na KS, Cho SJ, Kang SG. Low D-serine levels in schizophrenia: a systematic review and meta-analysis. Neurosci Lett. (2016) 634:4251. doi: 10.1016/j.neulet.2016.10.006

47. Kantrowitz JT, Woods SW, Petkova E, Cornblatt B, Corcoran CM, Chen $\mathrm{H}$, et al. D-serine for the treatment of negative symptoms in individuals at clinical high risk of schizophrenia: a pilot, double-blind, placebocontrolled, randomised parallel group mechanistic proof-of-concept trial. Lancet Psychiatry. (2015) 2:403-12. doi: 10.1016/S2215-0366(15)00098-X

48. Kantrowitz JT, Epstein ML, Lee M, Lehrfeld N, Nolan KA, Shope C, et al. Improvement in mismatch negativity generation during D-serine treatment in schizophrenia: correlation with symptoms. Schizophr Res. (2018) 191:709. doi: 10.1016/j.schres.2017.02.027

49. Ermilov M, Gelfin E, Levin R, Lichtenberg P, Hashimoto K, Javitt DC, et al. A pilot double-blind comparison of D-serine and high-dose olanzapine in treatment-resistant patients with schizophrenia. Schizophr Res. (2013) 150:604-5. doi: 10.1016/j.schres.2013.09.018

50. Capitao LP, Forsyth J, Thomaidou MA, Condon MD, Harmer CJ, Burnet PW. A single administration of 'microbial' D-alanine to healthy volunteers augments reaction to negative emotions: a comparison with D-serine. $J$ Psychopharmacol. (2020) 34:557-66. doi: 10.1177/0269881120908904

51. Heresco-Levy U, Durrant AR, Ermilov M, Javitt DC, Miya K, Mori H. Clinical and electrophysiological effects of D-serine in a schizophrenia patient positive for anti-N-methyl-D-aspartate receptor antibodies. Biol Psychiatry. (2015) 77:e27-9. doi: 10.1016/j.biopsych.2014.08.023

52. Tsai G, Yang P, Chung LC, Lange N, Coyle JT. D-serine added to antipsychotics for the treatment of schizophrenia. Biol Psychiatry. (1998) 44:1081-9. doi: 10.1016/S0006-3223(98)00279-0

53. Tsai GE, Yang P, Chung LC, Tsai IC, Tsai CW, Coyle JT. D-serine added to clozapine for the treatment of schizophrenia. Am J Psychiatry. (1999) 156:1822-5.

54. Heresco-Levy U, Javitt DC, Ebstein R, Vass A, Lichtenberg P, Bar G, et al. D-serine efficacy as add-on pharmacotherapy to risperidone and olanzapine for treatment-refractory schizophrenia. Biol Psychiatry. (2005) 57:577-85. doi: 10.1016/j.biopsych.2004.12.037

55. Lane HY, Chang YC, Liu YC, Chiu CC, Tsai GE. Sarcosine or D-serine add-on treatment for acute exacerbation of schizophrenia: a randomized, doubleblind, placebo-controlled study. Arch Gen Psychiatry. (2005) 62:1196204. doi: 10.1001/archpsyc.62.11.1196

56. Heresco-Levy U, Vass A, Bloch B, Wolosker H, Dumin E, Balan L, et al. Pilot controlled trial of D-serine for the treatment of posttraumatic stress disorder. Int J Neuropsychopharmacol. (2009) 12:127582. doi: 10.1017/S1461145709000339

57. Lane HY, Lin CH, Huang YJ, Liao CH, Chang YC, Tsai GE. A randomized, double-blind, placebo-controlled comparison study of sarcosine $(\mathrm{N}-$ methylglycine) and D-serine add-on treatment for schizophrenia. Int $J$ Neuropsychopharmacol. (2010) 13:451-60. doi: 10.1017/S1461145709990939

58. Gelfin E, Kaufman Y, Korn-Lubetzki I, Bloch B, Kremer I, Javitt DC, et al. D-serine adjuvant treatment alleviates behavioural and motor symptoms in Parkinson's disease. Int J Neuropsychopharmacol. (2012) 15:543-9. doi: 10.1017/S1461145711001015

59. D'souza DC, Radhakrishnan R, Perry E, Bhakta S, Singh NM, Yadav $\mathrm{R}$, et al. Feasibility, safety, and efficacy of the combination of Dserine and computerized cognitive retraining in schizophrenia: an international collaborative pilot study. Neuropsychopharmacology. (2013) 38:492-503. doi: 10.1038/npp.2012.208

60. Weiser M, Heresco-Levy U, Davidson M, Javitt DC, Werbeloff N, Gershon AA, et al. A multicenter, add-on randomized controlled trial of low-dose D-serine for negative and cognitive symptoms of schizophrenia. J Clin Psychiatry. (2012) 73:e728-34. doi: 10.4088/JCP.11m07031 
61. Lemmon ME, Grados M, Kline T, Thompson CB, Ali SF, Singer HS. Efficacy of glutamate modulators in tic suppression: a double-blind, randomized control trial of D-serine and riluzole in tourette syndrome. Pediatr Neurol. (2015) 52:629-34. doi: 10.1016/j.pediatrneurol.2015.02.002

62. Levin R, Dor-Abarbanel AE, Edelman S, Durrant AR, Hashimoto K, Javitt DC, et al. Behavioral and cognitive effects of the N-methyl$\mathrm{D}$-aspartate receptor co-agonist $\mathrm{D}$-serine in healthy humans: initial findings. J Psychiatr Res. (2015) 61:188-95. doi: 10.1016/j.jpsychires.2014. 12.007

63. Avellar M, Scoriels L, Madeira C, Vargas-Lopes C, Marques P, Dantas C, et al. The effect of D-serine administration on cognition and mood in older adults. Oncotarget. (2016) 7:11881-8. doi: 10.18632/oncotarget.7691

64. Wegner SA, Hu B, De Oliveira Sergio T, Darevsky D, Kwok CC, Lei $\mathrm{K}$, et al. A novel NMDA receptor-based intervention to suppress compulsion-like alcohol drinking. Neuropharmacology. (2019) 157:107681. doi: 10.1016/j.neuropharm.2019.107681

65. Madeira C, Lourenco MV, Vargas-Lopes C, Suemoto CK, Brandão CO, Reis $\mathrm{T}$, et al. D-serine levels in Alzheimer's disease: implications for novel biomarker development. Transl Psychiatry. (2015) 5:e561. doi: 10.1038/tp.2015.52

66. Malkesman O, Austin DR, Tragon T, Wang G, Rompala G, Hamidi $\mathrm{AB}$, et al. Acute $\mathrm{D}$-serine treatment produces antidepressantlike effects in rodents. Int J Neuropsychopharmacol. (2012) 15:1135-48. doi: 10.1017/S1461145711001386

67. Wei IH, Chen KT, Tsai MH, Wu CH, Lane HY, Huang CC. Acute amino acid D-serine administration, similar to ketamine, produces antidepressant-like effects through identical mechanisms. J Agric Food Chem. (2017) 65:10792803. doi: 10.1021/acs.jafc.7b04217

68. Andreasen NC. The Scale for the Assessment of Negative Symptoms (SANS). Iowa City, IA: The University of Iowa (1984).

69. Kay SR, Fiszbein A, Opler LA. The positive and negative syndrome scale (PANSS) for schizophrenia. Schizophr Bull. (1987) 13:261-76. doi: 10.1093/schbul/13.2.261

70. Tsai GE, Yang P, Chang YC, Chong MY. D-alanine added to antipsychotics for the treatment of schizophrenia. Biol Psychiatry. (2006) 59:2304. doi: 10.1016/j.biopsych.2005.06.032

71. Javitt DC, Malhotra AK, Woods SW, Kantrowitz JT, Cornblatt BA, Mathalon DH. Dose-finding PK/PD study of D-serine in schizophrenia: effects on symptoms and neurocognition. Neuropharmacology. (2008) 33.

72. Nilsson M, Carlsson A, Carlsson ML. Glycine and D-serine decrease MK801-induced hyperactivity in mice. J Neural Transm. (1997) 104:1195205. doi: 10.1007/BF01294720

73. Nuechterlein KH, Green MF, Kern RS, Baade LE, Barch DM, Cohen JD, et al. The MATRICS consensus cognitive battery, part 1: test selection, reliability, and validity. Am J Psychiatry. (2008) 165:20313. doi: 10.1176/appi.ajp.2007.07010042

74. Panizzutti R, Fisher M, Garrett C, Man WH, Sena W, Madeira C, et al. Association between increased serum $\mathrm{D}$-serine and cognitive gains induced by intensive cognitive training in schizophrenia. Schizophr Res. (2019) 207:63-9. doi: 10.1016/j.schres.2018.04.011

75. Hons J, Zirko R, Vasatova M, Doubek P, Klimova B, Masopust J, et al. Impairment of executive functions associated with lower D-serine serum levels in patients with schizophrenia. Front Psychiatry. (2021) 12:514579. doi: 10.3389/fpsyt.2021.514579

76. Kantrowitz JT, Swerdlow NR, Dunn W, Vinogradov S. Auditory system target engagement during plasticity-based interventions in schizophrenia: a focus on modulation of n-methyl-d-aspartate-type glutamate receptor function. Biol Psychiatry Cogn Neurosci Neuroimaging. (2018) 3:58190. doi: 10.1016/j.bpsc.2018.02.002

77. Kantrowitz JT. N-methyl-d-aspartate-type glutamate receptor modulators and related medications for the enhancement of auditory system plasticity in schizophrenia. Schizophr Res. (2019) 207:70-9. doi: 10.1016/j.schres.2018.02.003

78. Brummel C, Vedananda S, Doller D, Wong D, Gallegos R, Liu J, et al. CTP692: selective deuterium modification of D-serine markedly decreases renal toxicity in preclinical testing. In: ACT 39th Annual Meeting. West Palm Beach, FL (2018).
79. Deng A, Thomson SC. Renal NMDA receptors independently stimulate proximal reabsorption and glomerular filtration. Am J Physiol Renal Physiol. (2009) 296:F976-82. doi: 10.1152/ajprenal.90391.2008

80. Anderson M, Suh JM, Kim EY, Dryer SE. Functional NMDA receptors with atypical properties are expressed in podocytes. Am J Physiol Cell Physiol. (2011) 300:C22-32. doi: 10.1152/ajpcell.00268. 2010

81. Dryer SE. Glutamate receptors in the kidney. Nephrol Dial Transplant. (2015) 30:1630-8. doi: 10.1093/ndt/gfv028

82. Fishman WH, Artom C. Serine injury. J Biol Chem. (1942) 145:3456. doi: 10.1016/S0021-9258(18)45040-5

83. Morehead R, Fishman W, Artom C. Renal injury in the rat following the administration of serine by stomach tube. Am J Pathology. (1945) 21:803-15.

84. Morehead R, Poe W, Williams J, Lazenby M. The influence of age and species on the nephrotoxic action of DL-serine. Am J Pathology. (1946) 21:803-15.

85. Ganote CE, Peterson DR, Carone FA. The nature of D-serine-induced nephrotoxicity. Am J Pathol. (1974) 77:269-82.

86. Carone FA, Ganote CE. D-serine nephrotoxicity. The nature of proteinuria, glucosuria, and aminoaciduria in acute tubular necrosis. Arch Pathol. (1975) 99:658-62.

87. Williams RE, Jacobsen $M$, Lock EA. $1 \mathrm{H}$ NMR pattern recognition and 31P NMR studies with d-Serine in rat urine and kidney, timeand dose-related metabolic effects. Chem Res Toxicol. (2003) 16:120716. doi: $10.1021 / \mathrm{tx} 030019 \mathrm{q}$

88. Silbernagl S, Volker K, Dantzler WH. D-Serine is reabsorbed in rat renal pars recta. Am J Physiol. (1999) 276:F85763. doi: 10.1152/ajprenal.1999.276.6.F857

89. Kaltenbach JP, Ganote CE, Carone FA. Renal tubular necrosis induced by compounds structurally related to D-serine. Exp Mol Pathol. (1979) 30:20914. doi: 10.1016/0014-4800(79)90054-6

90. Huang Y, Nishikawa T, Satoh K, Iwata T, Fukushima T, Santa T, et al. Urinary excretion of D-serine in human: comparison of different ages and species. Biol Pharm Bull. (1998) 21:156-62. doi: 10.1248/bpb.21.156

91. Krug AW, Volker K, Dantzler WH, Silbernagl S. Why is D-serine nephrotoxic and alpha-aminoisobutyric acid protective? Am J Physiol Renal Physiol. (2007) 293:F382-90. doi: 10.1152/ajprenal.00441.2006

92. Orozco-Ibarra M, Medina-Campos ON, Sanchez-Gonzalez DJ, MartinezMartinez CM, Floriano-Sanchez E, Santamaria A, et al. Evaluation of oxidative stress in D-serine induced nephrotoxicity. Toxicology. (2007) 229:123-35. doi: 10.1016/j.tox.2006.10.008

93. Soto A, Delraso NJ, Schlager JJ, Chan VT. D-Serine exposure resulted in gene expression changes indicative of activation of fibrogenic pathways and downregulation of energy metabolism and oxidative stress response. Toxicology. (2008) 243:177-92. doi: 10.1016/j.tox.2007.10.009

94. Usuda N, Yokota S, Hashimoto T, Nagata T. Immunocytochemical localization of D-amino acid oxidase in the central clear matrix of rat kidney peroxisomes. J Histochem Cytochem. (1986) 34:170918. doi: $10.1177 / 34.12 .2878022$

95. Perotti ME, Gavazzi E, Trussardo L, Malgaretti N, Curti B. Immunoelectron microscopic localization of D-amino acid oxidase in rat kidney and liver. Histochem J. (1987) 19:157-69. doi: 10.1007/BF01695140

96. Konno R, Uchiyama S, Yasumura Y. Intraspecies and interspecies variations in the substrate specificity of D-amino acid oxidase. Comp Biochem Physiol B. (1982) 71:735-8. doi: 10.1016/0305-0491(82)90490-4

97. Frattini LF, Piubelli L, Sacchi S, Molla G, Pollegioni L. Is rat an appropriate animal model to study the involvement of D-serine catabolism in schizophrenia? Insights from characterization of D-amino acid oxidase. FEBS J. (2011) 278:4362-73. doi: 10.1111/j.1742-4658.2011.08354.x

98. Tseng YS, Liao $\mathrm{CH}, \mathrm{Wu} \mathrm{WB}, \mathrm{Ma}$ MC. N-methyl-d-aspartate receptor hyperfunction contributes to D-serine-mediated renal insufficiency. Am J Physiol Renal Physiol. (2021) 320:F799813. doi: 10.1152/ajprenal.00461.2020

99. Kragh-Hansen U, Sheikh MI. Serine uptake by luminal and basolateral membrane vesicles from rabbit kidney. J Physiol. (1984) 354:55-67. doi: 10.1113/jphysiol.1984.sp015361

100. Kimura T, Hesaka A, Isaka Y. D-Amino acids and kidney diseases. Clin Exp Nephrol. (2020) 24:404-10. doi: 10.1007/s10157-020-01862-3 
101. Iwakawa H, Makabe S, Ito T, Yoshimura T, Watanabe H. Urinary Dserine level as a predictive biomarker for deterioration of renal function in patients with atherosclerotic risk factors. Biomarkers. (2019) 24:15965. doi: 10.1080/1354750X.2018.1528632

102. Suzuki M, Gonda Y, Yamada M, Vandebroek AA, Mita M, Hamase $\mathrm{K}$, et al. Serum D-serine accumulation after proximal renal tubular damage involves neutral amino acid transporter Asc-1. Sci Rep. (2019) 9:16705. doi: 10.1038/s41598-019-53302-2

103. Sasabe J, Suzuki M, Miyoshi Y, Tojo Y, Okamura C, Ito S, et al. Ischemic acute kidney injury perturbs homeostasis of serine enantiomers in the body fluid in mice: early detection of renal dysfunction using the ratio of serine enantiomers. PLOS ONE. (2014) 9:e86504. doi: 10.1371/journal.pone.0086504

104. Nagata Y, Akino T, Ohno K, Kataoka Y, Ueda T, Sakurai T, et al. Free D-amino acids in human plasma in relation to senescence and renal diseases. Clin Sci. (1987) 73:105-8. doi: 10.1042/cs0730105

105. Kimura T, Hamase K, Miyoshi Y, Yamamoto R, Yasuda K, Mita $\mathrm{M}$, et al. Chiral amino acid metabolomics for novel biomarker screening in the prognosis of chronic kidney disease. Sci Rep. (2016) 6:26137. doi: $10.1038 /$ srep 26137

106. Hesaka A, Sakai S, Hamase K, Ikeda T, Matsui R, Mita M, et al. D-Serine reflects kidney function and diseases. Sci Rep. (2019) 9:5104. doi: 10.1038/s41598-019-41608-0

107. Hesaka A, Yasuda K, Sakai S, Yonishi H, Namba-Hamano T, Takahashi A, et al. Dynamics of D-serine reflected the recovery course of a patient with rapidly progressive glomerulonephritis. CEN Case Rep. (2019) 8:297300. doi: 10.1007/s13730-019-00411-6

108. Hasegawa H, Masuda N, Natori H, Shinohara Y, Ichida K. Pharmacokinetics and toxicokinetics of D-serine in rats. J Pharm Biomed Anal. (2019) 162:26471. doi: 10.1016/j.jpba.2018.09.026

109. Okada A, Nangaku M, Jao TM, Maekawa H, Ishimono Y, Kawakami $\mathrm{T}$, et al. D-serine, a novel uremic toxin, induces senescence in human renal tubular cells via GCN2 activation. Sci Rep. (2017) 7:11168. doi: 10.1038/s41598-017-11049-8

110. Huhn M, Nikolakopoulou A, Schneider-Thoma J, Krause M, Samara M, Peter N, et al. Comparative efficacy and tolerability of 32 oral antipsychotics for the acute treatment of adults with multi-episode schizophrenia: a systematic review and network meta-analysis. Lancet. (2019) 394:93951. doi: 10.1016/S0140-6736(19)31135-3

111. Meftah AM, Deckler E, Citrome L, Kantrowitz JT. New discoveries for an old drug: a review of recent olanzapine research. Postgrad Med. (2020) 132:80-90. doi: 10.1080/00325481.2019.1701823

112. Suzuki M, Sasabe J, Furuya S, Mita M, Hamase K, Aiso S. Type 1 diabetes mellitus in mice increases hippocampal $\mathrm{D}$-serine in the acute phase after streptozotocin injection. Brain Res. (2012) 1466:16776. doi: 10.1016/j.brainres.2012.05.042

113. Yang J, Song Y, Wang H, Liu C, Li Z, Liu Y, et al. Insulin treatment prevents the increase in D-serine in hippocampal CA1 area of diabetic rats. Am J Alzheimers Dis Other Demen. (2015) 30:2018. doi: 10.1177/1533317514545379

114. Molnar E, Varadi A, Mcilhinney RA, Ashcroft SJ. Identification of functional ionotropic glutamate receptor proteins in pancreatic beta-cells and in islets of langerhans. FEBS Lett. (1995) 371:253-7. doi: 10.1016/0014-5793(95)00890-L

115. Marquard J, Otter S, Welters A, Stirban A, Fischer A, Eglinger J, et al. Characterization of pancreatic NMDA receptors as possible drug targets for diabetes treatment. Nat Med. (2015) 21:363-72. doi: 10.1038/ nm. 3822

116. Lockridge A, Gustafson E, Wong A, Miller RF, Alejandro EU. Acute D-serine Co-Agonism of beta-Cell NMDA receptors potentiates glucose-stimulated insulin secretion and excitatory beta-cell membrane activity. Cells. (2021) 10:93. doi: 10.3390/cells10010093

117. Lockridge AD, Baumann DC, Akhaphong B, Abrenica A, Miller RF, Alejandro EU. Serine racemase is expressed in islets and contributes to the regulation of glucose homeostasis. Islets. (2016) 8:195-206. doi: 10.1080/19382014.2016.1260797

118. Ndiaye FK, Ortalli A, Canouil M, Huyvaert M, Salazar-Cardozo C, Lecoeur $\mathrm{C}$, et al. Expression and functional assessment of candidate type 2 diabetes susceptibility genes identify four new genes contributing to human insulin secretion. Mol Metab. (2017) 6:459-70. doi: 10.1016/j.molmet.2017.03.011

119. Suwandhi L, Hausmann S, Braun A, Gruber T, Heinzmann SS, Galvez EJC, et al. Chronic D-serine supplementation impairs insulin secretion. Mol Metab. (2018) 16:191-202. doi: 10.1016/j.molmet.2018.07.002

120. Yamauchi C, Fujita S, Obara T, Ueda T. Effects of room temperature on reproduction, body and organ weights, food and water intakes, and hematology in mice. Jikken Dobutsu. (1983) 32:1-11. doi: 10.1538/expanim1978.32.1_1

121. Sasaki T, Kinoshita Y, Matsui S, Kakuta S, Yokota-Hashimoto H, Kinoshita $\mathrm{K}$, et al. N-methyl-d-aspartate receptor coagonist D-serine suppresses intake of high-preference food. Am J Physiol Regul Integr Comp Physiol. (2015) 309:R561-75. doi: 10.1152/ajpregu.00083.2015

122. Sasaki T, Matsui S, Kitamura T. Control of appetite and food preference by nmda receptor and its co-agonist D-serine. Int J Mol Sci. (2016) 17:1081. doi: 10.3390/ijms17071081

123. Bentley-Lewis R, Huynh J, Xiong G, Lee H, Wenger J, Clish C, et al. Metabolomic profiling in the prediction of gestational diabetes mellitus. Diabetologia. (2015) 58:1329-32. doi: 10.1007/s00125-015-3553-4

124. Cobb J, Eckhart A, Perichon R, Wulff J, Mitchell M, Adam KP, et al. A novel test for IGT utilizing metabolite markers of glucose tolerance. J Diabetes Sci Technol. (2015) 9:69-76. doi: 10.1177/1932296814553622

125. Inagawa $\mathrm{K}$, Hiraoka $\mathrm{T}$, Kohda $\mathrm{T}$, Yamadera W, Takahashi M. Subjective effects of glycine ingestion before bedtime on sleep quality. Sleep Biol Rhythms. (2006) 4:75-7. doi: 10.1111/j.1479-8425.2006.00193.x

126. Kawai N, Sakai N, Okuro M, Karakawa S, Tsuneyoshi Y, Kawasaki $\mathrm{N}$, et al. The sleep-promoting and hypothermic effects of glycine are mediated by NMDA receptors in the suprachiasmatic nucleus. Neuropsychopharmacology. (2015) 40:1405-16. doi: 10.1038/npp.2014.326

127. Ghasemi M, Rezania F, Lewin J, Moore KP, Mani AR. d-Serine modulates neurogenic relaxation in rat corpus cavernosum. Biochem Pharmacol. (2010) 79:1791-6. doi: 10.1016/j.bcp.2010.02.007

128. Kantrowitz JT. The potential role of lumateperone-something borrowed? Something new? JAMA Psychiatry. (2020) 77:3434. doi: 10.1001/jamapsychiatry.2019.4265

129. Shimizu S, Sogabe S, Yanagisako R, Inada A, Yamanaka M, Iha HA, et al. Glycine-Binding site stimulants of NMDA receptors alleviate extrapyramidal motor disorders by activating the nigrostriatal dopaminergic pathway. Int J Mol Sic. (2017) 18:1416. doi: 10.3390/ijms18071416

130. Van Berckel BN, Lipsch C, Gispen-De Wied C, Wynne HJ, Blankenstein MA, Van Ree JM, et al. The partial NMDA agonist D-cycloserine stimulates LH secretion in healthy volunteers. Psychopharmacology. (1998) 138:1907. doi: $10.1007 /$ s002130050662

131. Kantrowitz JT, Milak MS, Mao X, Shungu DC, Mann JJ. dCycloserine, an NMDA glutamate receptor glycine site partial agonist, induces acute increases in brain glutamate plus glutamine and GABA comparable to ketamine. Am J Psychiatry. (2016) 173:1241-2. doi: 10.1176/appi.ajp.2016.16060735

132. Dong Z, Grunebaum MF, Lan MJ, Wagner V, Choo T-H, Milak MS, et al. Relationship of brain glutamate response to D-cycloserine and lurasidone to antidepressant response in bipolar depression: a pilot study. Front Psychiatry. (2021) 12:863. doi: 10.3389/fpsyt.2021.653026

133. Mitchell J, Paul P, Chen HJ, Morris A, Payling M, Falchi M, et al. Familial amyotrophic lateral sclerosis is associated with a mutation in D-amino acid oxidase. Proc Natl Acad Sci USA. (2010) 107:755661. doi: 10.1073/pnas.0914128107

134. Sasabe J, Chiba T, Yamada M, Okamoto K, Nishimoto I, Matsuoka M, et al. D-serine is a key determinant of glutamate toxicity in amyotrophic lateral sclerosis. EMBO J. (2007) 26:4149-59. doi: 10.1038/sj.emboj.7601840

135. Lee A, Arachchige BJ, Henderson R, Pow D, Reed S, Aylward J, et al. Elevated plasma levels of D-serine in some patients with amyotrophic lateral sclerosis. Amyotroph Lateral Scler Frontotemporal Degener. (2021) 22:20610. doi: 10.1080/21678421.2020.1832120

136. Rais R, Thomas AG, Wozniak K, Wu Y, Jaaro-Peled H, Sawa A, et al. Pharmacokinetics of oral D-serine in D-amino acid oxidase knockout mice. Drug Metab Dispos. (2012) 40:2067-73. doi: 10.1124/dmd.112.046482

137. Gonzalez-Hernandez JC, Aguilera-Aguirre L, Perez-Vazquez V, Ramirez J, Clemente-Guerrero M, Cortes-Rojo C, et al. Effect of D-amino acids on 
some mitochondrial functions in rat liver. Amino Acids. (2003) 24:1639. doi: 10.1007/s00726-002-0317-5

138. Asakawa T, Onizawa M, Saito C, Hikichi R, Yamada D, Minamidate A, et al. Oral administration of D-serine prevents the onset and progression of colitis in mice. J Gastroenterol. (2021). doi: 10.1007/s00535-021-01792-1. [Epub ahead of print].

139. Ghasemi-Kasman M, Dehpour AR, Mani AR. D-serine modulates nonadrenergic non-cholinergic contraction of lower esophageal sphincter in rats. Eur J Pharmacol. (2012) 696:155-60. doi: 10.1016/j.ejphar.2012. 09.011

140. Mcgee MA, Abdel-Rahman AA. N-Methyl-D-Aspartate receptor signaling and function in cardiovascular tissues. J Cardiovasc Pharmacol. (2016) 68:97-105. doi: 10.1097/FJC.0000000000000398

141. Mcgee MA, Abdel-Rahman AA. Enhanced vascular neuronal nitric-oxide synthase-derived nitric-oxide production underlies the pressor response caused by peripheral N-methyl-D-aspartate receptor activation in conscious rats. J Pharmacol Exp Ther. (2012) 342:461-71. doi: 10.1124/jpet.112.194464

142. Aya AG, Robert E, Bruelle P, Lefrant JY, Juan JM, Peray P, et al. Effects of ketamine on ventricular conduction, refractoriness, and wavelength: potential antiarrhythmic effects: a high-resolution epicardial mapping in rabbit hearts. Anesthesiology. (1997) 87:1417-27. doi: 10.1097/00000542-199712000-00021

143. Camargo LH, Alves FH, Biojone C, Correa FM, Resstel LB, Crestani CC. Involvement of $\mathrm{N}$-methyl-D-aspartate glutamate receptor and nitric oxide in cardiovascular responses to dynamic exercise in rats. Eur J Pharmacol. (2013) 713:16-24. doi: 10.1016/j.ejphar.2013.04.046

144. Ferreira-Junior NC, Lagatta DC, Resstel LBM. Glutamatergic, GABAergic, and endocannabinoid neurotransmissions within the dorsal hippocampus modulate the cardiac baroreflex function in rats. Pflugers Arch. (2018) 470:395-411. doi: 10.1007/s00424-017-2083-y

145. Gillies MJ, Huang Y, Hyam JA, Aziz TZ, Green AL. Direct neurophysiological evidence for a role of the human anterior cingulate cortex in central command. Auton Neurosci. (2018) 216:51-8. doi: 10.1016/j.autneu.2018.09.004

146. Slogoff S, Allen GW. The role of baroreceptors in the cardiovascular response to ketamine. Anesth Analg. (1974) 53:704-7. doi: 10.1213/00000539-197409000-00015

147. Hoka S, Takeshita A, Sasaki T, Yoshitake J. Preservation of baroreflex control of vascular resistance under ketamine anesthesia in rats. J Anesth. (1988) 2:207-12. doi: 10.1007/s0054080020207

148. Ogawa A, Uemura M, Kataoka Y, Ol K, Inokuchi T. Effects of ketamine on cardiovascular responses mediated by $\mathrm{N}$-methyl-D-aspartate receptor in the rat nucleus tractus solitarius. Anesthesiology. (1993) 78:1637. doi: 10.1097/00000542-199301000-00022

149. Jin YH, Bailey TW, Doyle MW, Li BY, Chang KS, Schild JH, et al. Ketamine differentially blocks sensory afferent synaptic transmission in medial nucleus tractus solitarius (mNTS). Anesthesiology. (2003) 98:12132. doi: 10.1097/00000542-200301000-00021

150. Bastings J, Van Eijk HM, Olde Damink SW, Rensen SS. D-amino acids in health and disease: a focus on cancer. Nutrients. (2019) 11:2205. doi: 10.3390/nu11092205

151. Du S, Wang Y, Alatrash N, Weatherly CA, Roy D, Macdonnell FM, et al. Altered profiles and metabolism of 1 - and d-amino acids in cultured human breast cancer cells vs. non-tumorigenic human breast epithelial cells. J Pharm Biomed Anal. (2019) 164:421-9. doi: 10.1016/j.jpba.2018. 10.047

152. Piossek C, Thierauch KH, Schneider-Mergener J, Volkmer-Engert $\mathrm{R}$, Bachmann MF, Korff $\mathrm{T}$, et al. Potent inhibition of angiogenesis by D,L-peptides derived from vascular endothelial growth factor receptor 2. Thromb Haemost. (2003) 90:501-10. doi: 10.1160/TH0302-0106

153. Gonzalez-Hernandez JA, Pita-Alcorta C, Padron A, Finale A, Galan L, Martinez E, et al. Basic visual dysfunction allows classification of patients with schizophrenia with exceptional accuracy. Schizophr Res. (2014) 159:226-33. doi: 10.1016/j.schres.2014.07.052
154. Pallerla S, Naik H, Singh S, Gauthier T, Sable R, Jois SD. Design of cyclic and d-amino acids containing peptidomimetics for inhibition of protein-protein interactions of HER2-HER3. J Pept Sci. (2018) 24:e3066. doi: 10.1002/psc.3066

155. Lane HY, Lin CH, Green MF, Hellemann G, Huang CC, Chen PW, et al. Addon treatment of benzoate for schizophrenia: a randomized, double-blind, placebo-controlled trial of D-amino acid oxidase inhibitor. JAMA Psychiatry. (2013) 70:1267-75. doi: 10.1001/jamapsychiatry.2013.2159

156. Lin $\mathrm{CH}$, Lin $\mathrm{CH}$, Chang YC, Huang YJ, Chen PW, Yang HT, et al. Sodium benzoate, a d-amino acid oxidase inhibitor, added to clozapine for the treatment of schizophrenia: a randomized, double-blind, placebo-controlled trial. Biol Psychiatry. (2017) 84:422-32. doi: 10.1016/j.biopsych.2017.12.006

157. Lin CY, Liang SY, Chang YC, Ting SY, Kao CL, Wu YH, et al. Adjunctive sarcosine plus benzoate improved cognitive function in chronic schizophrenia patients with constant clinical symptoms: a randomised, double-blind, placebo-controlled trial. World J Biol Psychiatry. (2017) 18:357-68. doi: 10.3109/15622975.2015.1117654

158. Ryan A, Baker A, Dark F, Foley S, Gordon A, Hatherill S, et al. The efficacy of sodium benzoate as an adjunctive treatment in early psychosis - CADENCE-BZ: study protocol for a randomized controlled trial. Trials. (2017) 18:165. doi: 10.1186/s13063-017-1908-5

159. Yoneyama T, Sato S, Sykes A, Fradley R, Stafford S, Bechar S, et al. Mechanistic multilayer quantitative model for nonlinear pharmacokinetics, target occupancy and pharmacodynamics (PK/TO/PD) Relationship of d-amino acid oxidase inhibitor, TAK-831 in mice. Pharm Res. (2020) 37:164. doi: 10.1007/s11095-020-02893-x

160. Williams RE, Lock EA. Sodium benzoate attenuates D-serine induced nephrotoxicity in the rat. Toxicology. (2005) 207:3548. doi: 10.1016/j.tox.2004.08.008

161. Konno R, Ikeda M, Yamaguchi K, Ueda Y, Niwa A. Nephrotoxicity of D-proparglyglycine in mice. Arch Toxicol. (2000) 74:4739. doi: 10.1007/s002040000156

162. Ferraris D, Duvall B, Ko YS, Thomas AG, Rojas C, Majer P, et al. Synthesis and biological evaluation of D-amino acid oxidase inhibitors. J Med Chem. (2008) 51:3357-9. doi: 10.1021/jm800200u

163. Hashimoto K, Fujita Y, Horio M, Kunitachi S, Iyo M, Ferraris D, et al. Co-Administration of a d-amino acid oxidase inhibitor potentiates the efficacy of D-serine in attenuating prepulse inhibition deficits after administration of dizocilpine. Biol Psychiatry. (2009) 65:11036. doi: 10.1016/j.biopsych.2009.01.002

164. Ferraris DV, Tsukamoto T. Recent advances in the discovery of D-amino acid oxidase inhibitors and their therapeutic utility in schizophrenia. Curr Pharm Des. (2011) 17:103-11. doi: 10.2174/138161211795049633

165. Nair AB, Jacob S. A simple practice guide for dose conversion between animals and human. J Basic Clin Pharm. (2016) 7:27-31. doi: 10.4103/0976-0105.177703

Conflict of Interest: The authors declare that the research was conducted in the absence of any commercial or financial relationships that could be construed as a potential conflict of interest.

Publisher's Note: All claims expressed in this article are solely those of the authors and do not necessarily represent those of their affiliated organizations, or those of the publisher, the editors and the reviewers. Any product that may be evaluated in this article, or claim that may be made by its manufacturer, is not guaranteed or endorsed by the publisher.

Copyright (C) 2021 Meftah, Hasegawa and Kantrowitz. This is an open-access article distributed under the terms of the Creative Commons Attribution License (CC BY). The use, distribution or reproduction in other forums is permitted, provided the original author(s) and the copyright owner(s) are credited and that the original publication in this journal is cited, in accordance with accepted academic practice. No use, distribution or reproduction is permitted which does not comply with these terms. 